\title{
The regional management of fisheries in European Western Waters
}

\author{
Le Floc'h Pascal ${ }^{1,2,{ }^{*}}$, Murillas Arantza ${ }^{1}$, Aranda Martin ${ }^{1}$, Daures Fabienne ${ }^{1,2}$, Fitzpatrick Mike ${ }^{1}$, \\ Guyader Olivier $^{1,2}$, Hatcher Aaron ${ }^{1}$, Macher Claire ${ }^{1,2}$, Marchal Paul ${ }^{1,2}$
}

${ }^{1}$ Université de Brest, UMR Amure, Quimper, France

${ }^{2}$ Ifremer, France

* Corresponding author : Pascal Le Floch', email address : plefloch@univ-brest.fr amurillas@azti.es ; maranda@azti.es ; fabienne.daures@ifremer.fr ; mike.fitzpatrick@nuigalway.ie ; olivier.guyader@ifremer.fr ; aaron.hatcher@port.ac.uk ; claire.macher@ifremer.fr ; paul.marchal@ifremer.fr

\begin{abstract}
:
A survey of past and existing management measures applied to different fisheries in European Western Waters is analyzed as a typology of co-management between governments and stakeholders. Faced with increasing constraints on accessing fish stocks, management measures have evolved toward fishing rights individualization, limited access and various other specific measures. Restrictions on access have changed fishermen's behaviour in several significant ways. A comparative analysis, based on qualitative data collected through interviews and focus groups, is developed for fisheries from the following European countries: France, Ireland, Spain and the United Kingdom. Past and existing individual harvesting rights in the four countries are reviewed and compared.
\end{abstract}

Keywords : Management, Fishery governance, Common Fishery Policy (CFP)

\section{Introduction}

Managed under the CFP, the European Western Waters fisheries are commercially exploited by fishing fleets from different European countries, including France, Ireland, Spain and the United Kingdom. Various management measures have been put in place, both at national and regional level. At the national level, vessel decommissioning schemes were among the main 
measures developed in the framework of the first CFP reform (1993-2002). The second reform (2003-2012) was characterised by regional policies such as recovery and management plans.

A new CFP has been agreed by Council and Parliament to be effective from 1 January 2014 (Regulation (EU) No 1380/2013 of the European Parliament and of the Council) after a long public debate launched by the European Commission since 2011. The Green paper on reform of the CFP and the followed citizen's consultation reports outlined different proposals. These included five main policies: the implementation of discard bans, the objective of Maximum Sustainable Yield by 2015, the regionalisation of management measures, an emphasis on the social dimension and the promotion of Transferable Fisheries Concessions (TFCs). Rightsbased management has been presented by the EC as a more efficient management approach to reduce overcapacity and give more responsibility to the industry. TFCs have been promoted at the European level, acknowledging that safeguard clauses could be necessary to avoid concentration of property rights (CEC, 2009, p8). Moreover, relative stability should be progressively replaced by a more flexible tool, "such as allocating fishing rights” (CEC, 2009, p16).

The French State has gradually transferred authority for TAC and quota species management to the Producer's Organisations - PO - (Larabi et al., 2013). Under the management of subquotas by POs, new tools, such as landings limits per vessel have been developed (e.g., for hake, anchovy, sole, mackerel). Ireland has promoted the Celtic Sea Herring Management Advisory Committee, in addition to the North Western Regional Advisory Council, created in 2004 for strengthening dialogue between stakeholders (Fitzpatrick, 2014b). In Spain, a system of individual quotas for mackerel and horse mackerel has been introduced for purse seiners since 2013. These individual quotas are not tradable. With respect to the Basque offshore fleets, rights are allocated to individual vessels. POs can pool the individual rights of their members and manage them collectively. Quota transferability is possible within and across POs (Aranda et al. 2012). In the UK, the quota management system is similarly largely devolved to the POs, except in the case of inshore vessels (under $10 \mathrm{~m}$ in length) which are still managed centrally (by the Marine Management Organisation (MMO) in England and Wales). Quota trading is possible within and between POs (Hatcher, 1997; Appleby, 2013).

The main objective of this paper is to show how management measures have evolved toward fishing rights individualization and limited access among other measures within a general 
context of restrictions on fish stock access to the resources. Face to new regimes of fisheries management, governance structures at regional and national levels have been adapted. In particular, the increasing role of the fishermen's organisations (e.g. Producer Organizations - POs) in quota management will be analysed together with different forms of comanagement regimes. With this aim, a comparative methodology is developed for a case study concentrated on fisheries performed in the European Westerns Waters.

In particular, this paper looks at the experiences from (i) the French fishing fleets exploiting the Bay of Biscay sole, (ii) the Irish fleets targeting the Celtic Sea herring fishery, (iii) the Spanish Basque purse-seiners exploiting mackerel, anchovy and tuna and the off-shore trawlers targeting hake, megrim and anglerfish, (iv) the Southwest English demersal fishery. Faced with increasing constraints on accessing fish stocks, management measures have evolved for each local case study towards fishing rights individualisation, limited access and other specific management measures.

The paper is structured as follows: Section 2 lays out a conceptual approach to governance in fisheries management, highlighting the main themes involved at a regional level (governance issue, management measures). Section 3 describes the case studies by country across the Western Waters (in terms of species, gears and fleets). Section 4 explains the management governance at an EU and national levels, and inter-relationships between both levels. Past and existing management measures are presented in Section 5 based on stakeholder's experiences for all four countries. Finally, Section 6 presents a discussion of the main results showing progress realized during the second CFP reform (2003-2012).

\section{A conceptual approach of governance in fisheries management}

In the literature devoted to governance issues in fisheries (Schlager and Ostrom, 1992), fishermen organization, rights-based management, leadership, social capital and regionalization are the main concepts used to highlight the main academic themes for benchmarking in fisheries (Grafton et al., 2007).

One of the major recent trends in the fishing sector has been the increasing role of fishermen's organisations in quota management (Holland et al., 2013). In France and in the UK, the central administration has gradually transferred the allocation procedures for quotas to POs. In 
107 view of quota over-consumption situations, POs have had to introduce new rules within their 108 organizations to impose limitations on individual consumption by species. The 109 implementation of individual fishing rights (France, Spain, UK) or access restrictions (Celtic 110 Sea herring in Ireland) reflects the European debate on transferable fishing concessions (TFC) 111 within the third reform of the CFP (Symes, 2009).

113 Several kinds of rights-based management systems exist and quotas can be allocated to the 114 owner, the vessel, but also to a collective i.e. a community or fishermen organisation 115 (Costello et al., 2008). Quota can be spatial and concern one or several species. Their transferability is not necessarily without limits. Overall, a rights-based management system could be adapted to different fisheries. The success of rights-based management, specifically transferable fishing concessions in the new CFP reform (EC, 2013), depends on the governance arrangements which could be a top-down/bottom-up procedure or a regionalized approach (Hegland et al., 2012; Gezelius et al., 2010). Other assets required for better fisheries management such as leadership amongst direct users of fisheries (Guttierez et al., 2011). All attributes related to co-management (fishermen's organisation, social capital, 123 leadership, regionalisation, right-based management) are key-elements of the institutional 124 arrangements (Hilborn et al., 2005). Table 1 offers a synthesis of an analytical framework for 125 fisheries co-management describing five broad types. This paper will highlight the progress of 126 the different management measures in Western Waters by adopting different co-management 127 systems according to the typology presented in Table 1.

Table 1. Typology of co-management

\begin{tabular}{llcc}
\hline \multicolumn{1}{c}{ Type of co-management } & \multicolumn{1}{c}{ Relationships } & Nature of management \\
\hline $\begin{array}{l}\text { Top-down hierarchical } \\
\text { management by the state }\end{array}$ & $\begin{array}{l}\text { Minimal exchange of information } \\
\text { between government and users }\end{array}$ & Centralized \\
\hline $\begin{array}{l}\text { Co-management } \\
\text { consultation }\end{array}$ & $\begin{array}{l}\text { Extensive and formal mechanisms } \\
\text { for consultation }\end{array}$ & Centralized \\
\hline Co-management by partnership & $\begin{array}{l}\text { Government and users as decision- } \\
\text { making partners }\end{array}$ & Co-managed \\
\hline Co-management by delegation & Users as decision-makers, but & Decentralized \\
& endorsed by Government & Decentralized \\
\hline Industry self-management with & Users as decision-makers, & as d
\end{tabular}


reversal of the burden of proof informing Government

Source: adapted from Raakjaer, 2009 and Hegland et al., 2012

132

133

134

135

136

137

138

139

140

141

142

143

144

145

146

147

148

149

150

151

152

153

154

155

156

157

158

159

160

161

162

163

This typology is rooted in the classification proposed by Sen and Nielsen (1996), which considered five institutional arrangements between Government and local stakeholders. Only one type of fisheries management process can be defined as a pure co-management scheme (co-management by partnership), where Government and users of the marine resource (fishermen, processors, non-governmental organizations) act as decision-making partners (Jentoft, 1989). The four other alternatives adopt either a centralized or decentralized procedure. Detailed information on the different case studies follows.

\section{Methodology}

The European research project SOCIOEC is an interdisciplinary, European wide project bringing together scientists from several fisheries sciences with industry partners and other key stakeholders. The case studies investigated under the SOCIOEC research project are the Western Waters fisheries, the Baltic Sea, the Mediterranean Sea and the Black Sea, the North Sea, and the Pelagic fisheries. Non-EU fisheries are included for comparative assessment (Iceland, Australia, New-Zealand). In the case of the Western Waters, four countries (France, Ireland, Spain and UK), are compared for a better understanding of socio-economic effects of the main management principles under the CFP (SOCIOEC, 2013).

A comparative methodology, based on qualitative data collected through interviews and focus groups, is developed for each case study. Lists of past and existing management measures applied in Western Waters are analyzed against a typology of co-management between government and stakeholders. Restrictions on fish stocks access have changed fishermen's behaviour in several significant ways. This paper compares the experiences and outcomes of the four different Western Waters nations management approaches in the context of the current CFP reforms.

Spatial distribution of all segments indicates heterogeneous experiences in Western Waters (Figure 1). Spatial dynamics reveal highly different vessel movements at sea. Spanish fleets located in areas VI and VII are subjected to the largest distances. The Herring fishery exploited by the Irish fleets was concentrated on inshore spawning aggregations but fishing 
177 The main characteristics explored through interviews and focus groups are internal factors of

activity in the main fishery has moved further offshore in the past few years in order to avoid impacts on spawning fish. The various spatial locations raise specific organizational arrangements. The French and English vessels are concentrated near their own national coastlines.

Figure 1. Spatial distribution of fishing effort for the French, the Irish, the Spanish Basque and the English demersal fleets

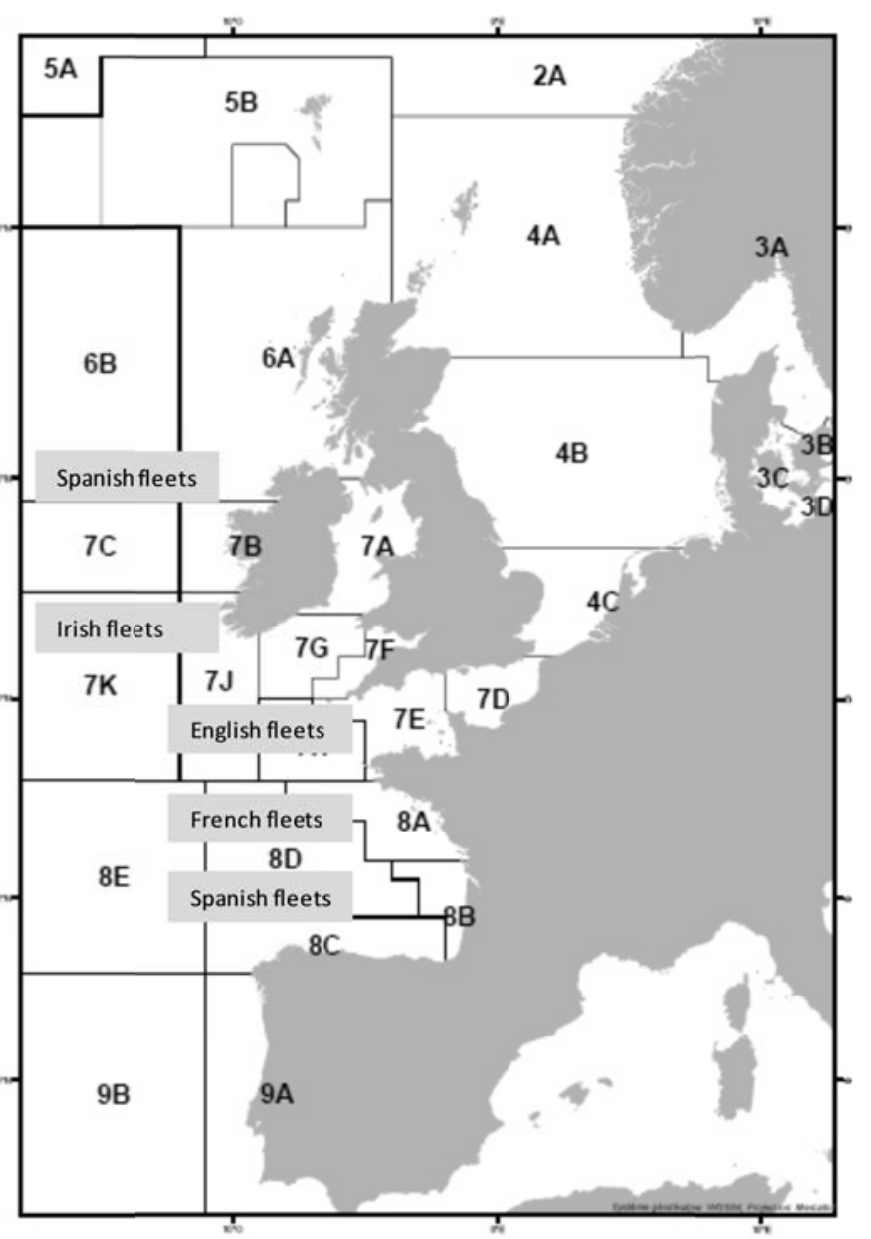

Source: Anonymous, 2013 regional and local fisheries. These internal factors can be rights and rules adopted by fishermen, their legitimacy and their enforcement compliance, power structures inside institutional and organizational arrangements, and leadership (Guttierez et al., 2011). These characteristics define decision-making arrangements. Semi-structured interviews and focus 
182 groups were conducted at different scales for each sub-case study in France, Ireland, Spain 183 and the UK, with the aim of achieving several objectives: to begin with, qualitative 184 information was collected on fishermen's incentives to change or adapt fishing behaviour in 185 view of tighter constraints for access regulation of stocks. A second issue relates to managers' 186 capabilities. The professional skills and qualifications of local and regional managers are key 187 elements in evaluating their ability to deal with external shocks. Another issue deserving 188 attention in the process of interviews and focus groups is the managers' use of financial 189 resources. New fisheries management measures require new methods of collecting and spending appropriated budgets. Finally, the success and failure of previous and existing management measures are also closely dependent on communication methods between managers and fishermen.

4. The fisheries, with particular reference to species, gears and fleets

Each country is characterized by multi-fleet and multi-species fishing, located in main areas of the European Western Waters. Detailed information about fishing areas, fleet characteristics and target species are shown in Table 2.

Table 2. Characteristics of the case studies

202

\begin{tabular}{|c|c|c|c|c|}
\hline Sub-case & ICES areas & Fleet & $\begin{array}{c}\text { Length } \\
\text { range } \\
\text { (meters) }\end{array}$ & Target Species \\
\hline \multirow{5}{*}{ The French fleets } & \multirow{5}{*}{$\begin{array}{c}\text { VIII } \\
\text { Bay of Biscay }\end{array}$} & \multirow{3}{*}{ Bottom trawlers } & $12-16 \mathrm{~m}$. & \multirow{3}{*}{ Nephrops, Sole, Hake } \\
\hline & & & $16-20 \mathrm{~m}$. & \\
\hline & & & $20-24 \mathrm{~m}$. & \\
\hline & & \multirow{2}{*}{ Gill-netters } & $<12 \mathrm{~m}$. & \multirow{2}{*}{ Sole, Hake } \\
\hline & & & $12-16 \mathrm{~m}$. & \\
\hline \multirow{3}{*}{ The Spanish fleets } & \multirow{3}{*}{$\begin{array}{c}\text { VIII Bay of } \\
\text { Biscay } \\
\text { VI/VII }\end{array}$} & Purse-seiners & $20-38 \mathrm{~m}$. & Anchovy, Tuna, Mackerel \\
\hline & & Mixed trawlers & $30-43 \mathrm{~m}$. & \multirow{2}{*}{ Hake, Megrim, Anglerfish } \\
\hline & & Mixed Trawlers & $30-43 \mathrm{~m}$. & \\
\hline \multirow{4}{*}{ The Irish fleets } & \multirow{4}{*}{$\begin{array}{c}\text { VII } \\
\text { Celtic Sea }\end{array}$} & & $15-20 \mathrm{~m}$. & \multirow{3}{*}{$\begin{array}{c}\text { Herring, pelagic and } \\
\text { demersal }\end{array}$} \\
\hline & & Poryvalent & $20-24 \mathrm{~m}$. & \\
\hline & & & $>24 \mathrm{~m}$ & \\
\hline & & $\begin{array}{c}\text { The sentinel } \\
\text { fishery }\end{array}$ & $<15 \mathrm{~m}$ & Herring and shellfish \\
\hline \multirow{4}{*}{ The English fleets } & \multirow{4}{*}{ VII/VIII } & \multirow{2}{*}{ Trawlers, netters } & $10-24 \mathrm{~m}$. & \multirow{2}{*}{ Mixed demersal } \\
\hline & & & $24-40 \mathrm{~m}$. & \\
\hline & & \multirow{2}{*}{$\begin{array}{l}\text { Beam trawlers, } \\
\text { dredgers }\end{array}$} & $21 \mathrm{~m}$. & \multirow{2}{*}{ Sole, Plaice, Scallops } \\
\hline & & & $28 \mathrm{~m}$. & \\
\hline
\end{tabular}


205 French demersal fleets operating in the Bay of Biscay (BoB)

206 The demersal fishery in the Bay of Biscay is mainly exploited by French fishing fleets with 207 Spanish and Belgian fleets also catching hake and sole in this area. This fishery is of great 208 interest to scientists and professionals (fishermen and other stakeholders). Targeted species 209 include nephrops, sole and hake which are among the 10 most important commercial species 210 (in value) for the French fishing fleets. 700 French vessels of different sizes (less than 10 211 meters to more than 20 meters) with 2000 fishermen are involved in the Bay of Biscay demersal fishery. These vessels are mostly trawlers and gillnetters. Their total landings amount to 50,000 tons with a value of $€ 270 \mathrm{~m}$ yearly, representing more than $30 \%$ of the

214 French total landings value. With annual landings between 5,500 to 7,500 tons (€65 to €85 215 millions), sole is one of the three main commercial species at the national level. The BoB 216 landings for sole, mostly for the fresh market, contribute $60 \%$ of the sole national landings 217 with a value of $€ 55 \mathrm{~m}$ The French fleet accounts for around $90 \%$ of the total landings in the 218 Bay of Biscay sole fishery. French gillnetters are the major contributors to the sole catches, followed by French trawlers (targeting sole, cuttlefish, squid, hake or whiting) and Belgian beam trawlers (exploiting sole in the Bay of Biscay in summertime).

\section{Irish fleets targeting Celtic Sea Herring}

There are two distinct Irish fleets targeting Celtic Sea herring. The main fishery, which is allocated $89 \%$ of the Irish quota, comprises vessels mainly over 15 meters in length and has a mix of multipurpose vessels which switch between pelagic and demersal species throughout the year and solely pelagic vessels which use refrigerated sea water tanks to store their catch. There is also a small-scale fleet, known as the sentinel fishery, which is allocated $11 \%$ of the quota and which can fish inside a specific area closed to fishing by larger vessels in order to protect spawning herring. The numbers of vessels in this fleet have increased from 4 in 2009 to 16 in 2012. The majority of these vessels are approximately 10 meters in length. The main fishery occurs between September and November while the sentinel fishery occurs between

232 November and February. Both fleets (main and sentinel) are multispecies fleets. Many of the smaller sentinel fishery vessels target shellfish with pot fisheries outside of the herring season.

234 The multipurpose vessels in the main fishery usually focus on trawling for mixed demersal 235 species in the Celtic Sea when not fishing for herring while the pelagic vessels also target mackerel, other herring stocks, blue whiting, horse mackerel, sprat, albacore tuna and boarfish 
when not targeting Celtic Sea herring. All of these vessels fish use the method of pair pelagic trawling.

\section{Basque purse-seiner and trawler fleets (BoB and ICES areas VI and VII)}

The "Baka” trawlers of Spain and particularly the Basque country fleet (north-east of Spain) operate in ICES Sub-areas VI, VII and VIII a, b, d. "Baka” trawlers can be defined as a single vessel which trawls a "bottom net" operating in contact with the seabed. These vessels exploit multi-species fisheries targeting mainly, hake, anglerfish and megrim; the average storage capacity is 50 tons. Bottom pair trawlers comprise two vessels trawling a single very high vertical opening net. The main target species is hake. The Basque fleet currently includes 11 otter trawler fishing vessels, with an average length of 38 meters and an average power of 461 kWs. A single otter trawler crew is made up of 13 fishermen, with a fleet employing around 143 people. The most important social impact over the last decade is due to the decrease in vessel number. The size of the Basque trawler fleet fell by 60\% between 1992 and 2010 . Their total landings account for 140,000 tons with a total annual revenue of $€ 290 \mathrm{~m}$. The Basque fleet includes 42 purse-seiners of an average length of 32 meters and an average power of $467 \mathrm{kWs}$. A single purse seiner operates with 12 fishermen, with the fleet employing around 500 people. The fleet is multispecies, distributing its activity across the mackerel, anchovy and tuna seasons. The purse seiners can shift fishing gear to pole and line (using live bait), hand lines and trolling, depending on the species and fishing season. Their total landings amount to 19,000 tons with a total annual revenue of $€ 32 \mathrm{~m}$.

\section{SW English demersal fleets}

Most of the UK-registered vessels fishing in Western Waters (ICES sub-areas VII and VIII) belong to two POs: the South Western Fish Producers' Organisation (SWFPO) and the Cornish Fish Producers' Organisation (CFPO). Between them, these POs represent the majority of fishing vessels based in South West England (principally the counties of Devon and Cornwall), although they both also have member vessels from other parts of the UK. The UK Western Waters offshore demersal fleet includes beam trawlers, demersal trawlers, liners and netters. Main target stocks include sole, plaice, hake, megrim and monkfish. The principal landing ports for SW English vessels are Brixham in Devon (particularly for the SWFPO vessels) and Newlyn in Cornwall (for CFPO vessels). Other important landing ports include Plymouth in Devon and Looe in Cornwall, although landings are also made into French and Belgian ports. Brixham is a major port for beam trawlers landing sole and plaice as well as 
271 scallops. There is an important seasonal fishery for cuttlefish. Newlyn also receives

272 significant landings from liners, netters and demersal trawlers catching hake and megrim.

273 These high-value fisheries predominantly supply European export markets such as France and

274 Spain. There are just under 200 vessels in the CFPO, of which around 80 are inshore vessels

275 (10 meters or under in overall length). The SWFPO has about 70 over 10 meters vessels and

276 only 8 inshore vessels. Approximately half the offshore vessels in the SWFPO are beam

277 trawlers and/or scallop dredgers.

279 5. Management governance: national and EU and inter-relationships

281 The CFP, implemented in 1983, has been reformed three times, in 1992, 2002 and 2013

282 (Figure 2). In each instance, reforms aimed to preserve declining fish stocks. The late 1980s 283 saw the fishing industry become a victim of its own success: high prices for fish landings led 284 the industry to over-invest, which led to overfishing. Some claimed this was exacerbated by 285 EU fishing industry grants, which were seen as a good way to promote regional development. 286 The 2002 review withdrew the grants allocated to build new boats and provided incentives for 287 decommissioning existing vessels. Recovery plans were also adopted in relation to specific 288 threatened species, while management plans were implemented for some other stocks. In 289 addition, a Compliance Scoreboard was published for member states and a code of conduct 290 for responsible fishing was developed.

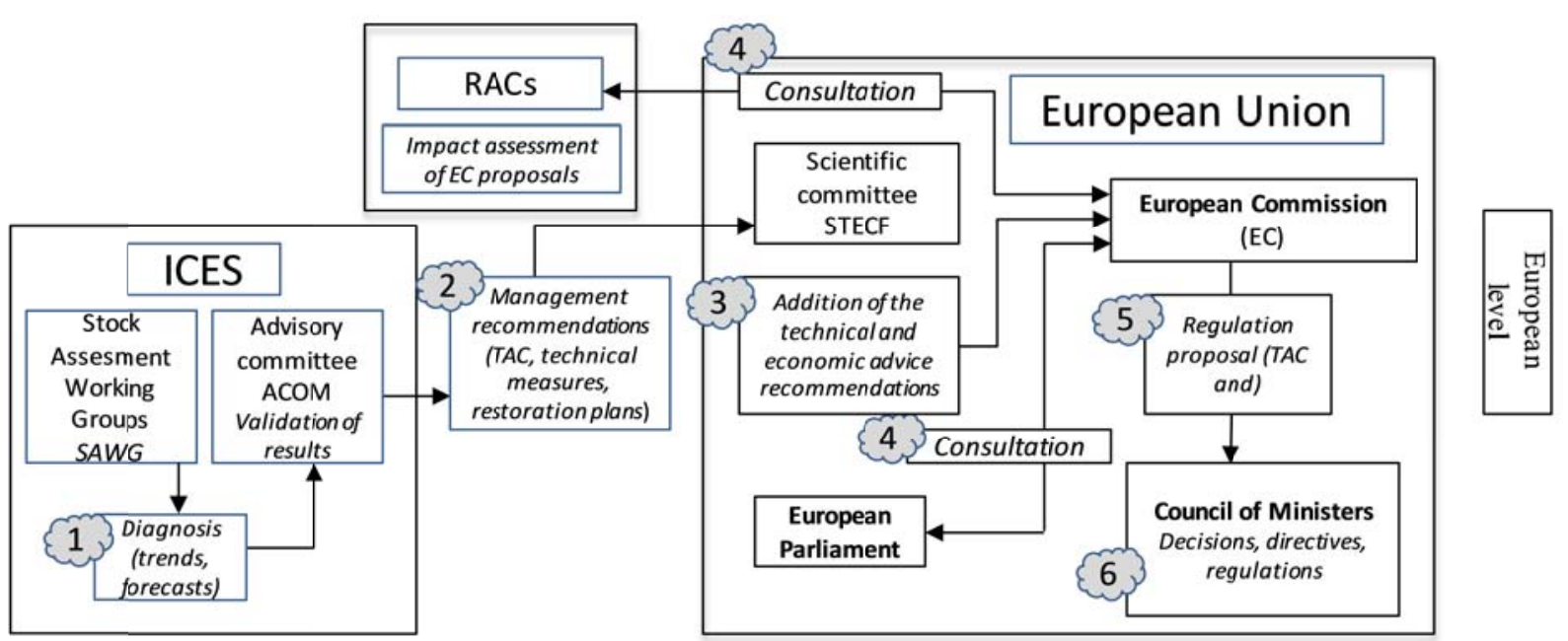


298 The third CFP came into force on January 1 2003, with the creation of the Regional Advisory 299 Councils (RACs). The RACs include stakeholders split into working groups. Focus group 300 methodology is well known in the fisheries fields, serving as advisory boards and stock and 301 impact assessments of European Commission proposals.

303 On 13 July 2011, the European Commission presented its proposals for the third reform of the 304 EU Common Fisheries Policy (Commission of the European Communities, 2009). These 305 included the implementation of discard bans, explicit reference to Maximum Sustainable 306 Yield as a management objective, more incentives given to strengthen the regionalisation of 307 management, an increased focus on social sustainability, and the promotion of Transferable 308 Fisheries Concessions (TFC). The fourth Common Fisheries Policy is being implemented 309 during the course of 2014 (European Commission, 2013).

\section{France}

312 Management responsibility for French quota involves three main players: The Department for 313 Marine Fisheries and Aquaculture is responsible for allocating and controlling national quotas 314 on behalf of the Ministry of Agriculture and Fisheries. Producer Organisations (POs) are 315 authorized by the Central State (Ministry of Agriculture and Fisheries) to manage sub-quotas. 31620 French POs were recognised by the EU in 2010 (14 located on the Atlantic coast). Vessel 317 owners form the third player in this structure, as members or non-members of one of the POs. 318 The adoption of TFC is officially non-applicable in France under the Fisheries Act adopted in 319 1997. The law prevents the transferability of fishing rights, stating that marine resource are common wealth. Moreover, fishing rights allocated by the central authority (the French Ministry of fisheries) to POs or vessels, as sub-quotas per species, are not transferable. In 2006, the legal framework has evolved to give more responsibility to POs (JORF, 2006). Track records per vessel were computed, based on the total landings registered in the years 2001, 2002 and 2003 (Larabi et al., 2013). Pioneer POs have experimented with new fisheries management using individual quotas (IQs), without transferability. One of the first fisheries using IQs has been the sole fishery in the Bay of Biscay, with a history of quota overconsumption.

\section{Ireland}


86\% of the Celtic Sea Herring TAC is allocated to Ireland and the fishery has in recent years been mainly exploited by Ireland. The only other significant players involved in the fishery are Dutch and Dutch owned vessels from France and Germany (Marine Institute, 2012). Management responsibility for the Irish quota rests with the Irish fisheries minister and the relevant staff from the Department of Agriculture, Food and the Marine. However in 2005 a management advisory committee which had been operating on an ad hoc basis since 2001 was officially recognized by the Fisheries Minister. This committee, the Celtic Sea Herring Management Advisory Committee (CSHMAC), although officially only advisory in status, following ministerial recognition, found that most of its advice has been accepted. Therefore the management of the fishery could be considered as an informal version of co-management. The committee consists of representatives of four POs, fishermen, processors, scientists, a marine mammal NGO and control authorities. The CSHMAC makes operational level decisions such as the length of the season and the size of weekly allocations within that period while the Minister retains control of who has access rights and in certain cases when the fishery will finish. In 2012 the Fisheries Minister introduced a new ruling which restricted access to the fishery for larger vessels based on a track record of landing a defined quantity of fish within a reference period.

\section{Spain}

In the case of the Basque country, fisheries institutions play a key role in the day-to-day fishing activity. The pelagic fleet is organised under the umbrella of the "cofradías", which are ancient institutions representing fishermen's (boat owners' and crew members') interests, and centralize trading of the fish caught by their members. In turn, POs regroup the industrial trawler owners. Their initial role was fish trading, but has evolved to include fishing activity management and the administration of all members' fishing rights and can even extend to proposing conservation and management measures (e.g. limiting landing quantities of small legally marketable fish to improve prices and sustain the stocks). "Cofradías" are now assembled under the umbrella of the PO model in order to access the powers that the EU's legal framework provides for POs, such as proposing market measures that are extended to other producers. Offshore POs are usually associated with both the South Western Waters RAC, and the North Western Waters RAC. Inshore POs take part in the South Western Waters RAC and the Pelagic RAC.

\section{$U K$}


In the UK quota management has been substantially devolved to the POs since the 1980s

365 (Hatcher, 1997). Each year the UK national quotas are allocated to the POs who then have responsibility for allocating quota to the individual vessels they represent and managing quota uptake throughout the year. Until 1999 PO quota allocations were based upon average landings of member vessels over the previous three years, but from 1999 these historical rights were “frozen” as Fixed Quota Allocations (FQAs). The FQA holdings of individual vessels now determine the percentages of the UK quotas which the POs receive each year. Each PO can determine how it chooses to allocate quota amongst its membership, for example using individual quotas (IQs) or monthly landings limits from a common quota pool. For the most part, quota uptake by the inshore (10m overall length and under) fleet as well as those

374 few offshore vessels which do not belong to a PO is managed directly by the national fisheries administrations or their appointed agencies (the Marine Management Organisation - MMO in the case of England and Wales). Most UK POs, including those described in this article, are legally constituted as “mutual” societies (fishermen’s organisation but a few are established as private companies. Although quota is not explicitly tradeable in the UK, FQA entitlements can be transferred between licences and there is an active in-year lease market for quota which takes advantage of relaxed rules permitting quota exchanges between POs.

In the late 2000s, individual authorisations were expanded in response to quota overconsumption. These fisheries management measures take various forms such as individual quota for the sole fishery (France), limited access for the Celtic Sea Herring fishery (Ireland), individual daily catch limits for mackerel and anchovy (purse seiners, Spain), individual quota for bluefin tuna (purse seiners, Spain), individual transferable quota for the Spanish trawlers, and "fixed quota allocations" for the UK. These management measures have sometimes called for new partnerships between Government and stakeholders (requiring new

391 forms of incentives, capabilities, financial resources, and communication). This section 392 presents various stakeholders' experiences from past and existing incentives, management 393 measures and their contribution to the sustainability of the fisheries, representing one of the 394 goals within the new Common Fishery Policy. 
397

398

399

400

401

402

403

404

405

406

407

408

409

410

411

412

413

414

415

416

417

418

419

420

421

422

423

424

425

426

427

428

429

430

The Bay of Biscay sole fishery has been under a management plan since 2002. Following a first recovery plan, a multiannual management plan was implemented in 2006 (EC $\mathrm{N}^{\circ}$ 388/2006). The first step of the multiannual management plan in 2008 was the restoration of the stock at a level of precautionary spawning biomass. Following the new framework of the CFP Reform, the Bay of Biscay sole management plan implemented in 2006 will become a Bay of Biscay multi-specific management plan. Quota management by POs mainly relies on a quota pooling system with redistribution among members. POs manage sub-quotas allocated by the member state that correspond to their members' rights based on the 2001-2003 track records. Following quota constraints, POs have introduced systems of individual landings limits by vessel. This measure was first used by two POs in 2006 in order to avoid penalties for regular over-consumption of their allocated sole sub-quotas (Larabi et al., 2013). In 2011, with the increasing sub-quota constraints, many POs generalised a limitation system on individual landings for at least the main sole producers, the sole gillnetters. The sole fishery in the Bay of Biscay is commercially exploited by trawlers and gill-netter fleets belonging to one of the nine POs located on the French Atlantic Coast. The 9 POs located on the Atlantic Coast manage $60 \%$ of the domestic sole landings. The other major contribution for this species comes from the Eastern Channel fisheries. The interviews highlighted a generalization of the sole sub-quotas' individual management. This situation results from a stronger or tighter constraint due to the lack of resource availability. Six of the nine POs involved in the sole fishery management implemented landings limits per vessel in 2012. However, an individual management system is seldom generalised for all vessels within a PO, but rather is established according to fishing activities or "metiers" (fish-gear associated to target species and fishing grounds) and/or vessel lengths. POs primarily apply individual limits to the larger sole producers, usually the largest sole gillnetters. This system is very limited for some POs owing to the absence of a global monitoring system. For example, the smallest producers for which sole is a by-catch are not concerned with individual limits but receive a global allocation. The criteria adopted for sole sub-quota management vary between POs. A few of them determine limits in proportion to the reference track records (2001-03 production average); some POs allocate quotas according to more recent track record keys, and other POs use maximal production over the last 10 years or a fixed package.

\section{Ireland: Restriction of access}

The area of rights based management represents one of the major problems facing the Irish Celtic Sea Herring fishery (Fitzpatrick, 2014a). Prior to 2012 there was an open access 
431 situation in the fishery for vessels under 25 meters in length which had an automatic 432 entitlement to fish for herring. The recent success in rebuilding the stock has resulted in a 433 classic free rider issue with increased numbers of larger vessels booking in to the fishery. 434 Many of these larger vessels had not participated in the fishery for much of the previous 435 decade despite holding valid Celtic Sea Herring licenses. Attempts by the CSHMAC to 436 address this issue in 2010 by specifying a preclusion on whitefish and shellfish fishing for the 437 period of the herring fishery for any vessel booking in did not have the desired effect partly 438 due to difficulties in obtaining timely information from the relevant Department officials. In 2012 a new access policy was published by the fisheries minister, (Dept. Agriculture, Food and Fisheries, 2012), which sought to limit access to vessels which landed Herring between 2006 and 2010. This has resulted in approximately 38 vessels qualifying for access to the fishery from 2012. Incidentally this is higher than the average participation over the previous 4 years.

Spain: Various forms of individualization

In the case of pelagic species, various forms of individualization of catch limits and fishing rights have been introduced over the last five years. The first step to the introduction of individual limits and rights was the allocation of proportions of the pelagic quotas to fishing techniques. In the case of the mackerel fishery, the national regulation was implemented in 2010 (Orden ARM/271/2010 ${ }^{1}$ ) with the aim of distributing the Spanish catch quota by gear, with $30 \%$ of the quota allocated for trawlers, $28 \%$ for purse seiners and 35\% for artisanal 452 fisheries. For all of them, 7\% of the catch should be kept for the second half of the year. Landing limits have been considered for the mackerel fishery in recent years. In 2009 daily 454 limits $^{2}$ within top-down hierarchical management by the Spanish administration were introduced. However, these limits were initially proposed by the PO concerned (i.e. OP Cantabrico), as extension of rules for all POs involved in the fishery ${ }^{3}$. The limits impose a constraint on catches and are not allocated on the basis of catch records. They are not transferable amongst vessels. Landings limits on anchovy are adopted within the cofradías and are usually respected by fishermen. It seems that these moral/social incentives are widely accepted because of the perceived legitimacy of the group's decisions. The rationale for the

\footnotetext{
${ }^{1}$ Orden ARM/271/2010, de 10 de febrero, por la que se establecen los criterios para el reparto y la gestión de la cuota de caballa, y se regula su captura y desembarque.

2 Orden ARM/2091/2008. In 2011, the Spanish administration introduced new daily limits by vessels.

${ }^{3}$ In accordance with Commision Regulation 696/2008 of 23 July 2008 laying down detailed rules for the application of Council Regulation (EC) No 104/2000 as regards the extension to non-members of certain rules adopted by producers' organisations in the fisheries sector.
} 
461

462

463

464

465

466

467

468

469

470

471

472

473

474

475

476

477

478

479

480

481

482

483

484

485

486

487

landings cap is both an improvement of the anchovy price, and a protection of the resource.

The collapse and closure of the anchovy fishery that occurred in 2004 seems to have triggered conservation measures and respect of group decisions. According to fishermen, the strategy to limit landings results in better prices (although not as good as initially expected). There are other factors that contribute to this. In 2008, a system of individual quotas for blue-fin tuna was introduced. The national quota was divided among diverse fishing techniques, including purse seining. Within each technology vessels receive individual quotas. According to the regulation in force (ARM/1753/2011 ${ }^{4}$ ) these can be pooled within a given fishermen's organization, being also tradable amongst the diverse Spanish fishing technologies e.g. from purse seiners to tuna farms. In this case self-management is adopted under the PO umbrella. For instance, in 2012, 70\% of the rights allocated to purse seiners fishing with live bait in the Bay of Biscay were transferred to a Spanish company in the Mediterranean, which carries out tuna farming (Anon. 2012). In 2013, the total fishing quota was temporarily transferred (just for that year) to a Spanish tuna farmer in the Mediterranean (Anon., 2012). In relation to the offshore fleet, in July 1997, the ministry passed Law 23/1997 that allows free trade of rights among companies owning vessels in the same list, without transferring the ownership of the vessel. In December 2006, the Order APA 3773/2006 ${ }^{6}$ established a system of ITQs for vessels over 100 GRT operating in ICES areas Vb, V, VII and VIIIa,b,d,e. This system was made permanent through the Order ARM/3812/2008 ${ }^{7}$.

\section{UK: Mixed views on quota trading}

In the UK there are mixed views on quota trading and this is to some extent reflected in the differences between POs in the way in which quota is allocated internally. In Scotland, for example, many of the PO administrations continue to take a strong position against quota trading and operate quota pools for all stocks. In England and Wales, more POs operate IQ systems for at least some stocks and some vessels. In the South West, the CFPO has adopted what is commonly known as a "pool-plus" system, whereby quota is pooled but individual

\footnotetext{
${ }^{4}$ Orden ARM/3315/2010, de 21 de diciembre, por la que se modifica la Orden ARM/271/2010, de 10 de febrero, por la que se establecen los criterios para el reparto y la gestión de la cuota de caballa, y se regula su captura y desembarque

${ }^{5}$ Ley 23-1997 reguladora de la pesca de altura en el Atlántico Nordeste.

${ }^{6}$ ORDEN APA/3773/2006, de 7 de diciembre, por la que se establecen para el año 2007, las condiciones de distribución y gestión de las cuotas asignadas a España de especies demersales, en aguas comunitarias no españolas, de las subzonas V b, VI, VII y VIII a, b, d, e del Consejo Internacional para la Exploración del Mar.

${ }^{7}$ ORDEN ARM/3812/2008, de 23 de diciembre, por la que se establecen las condiciones de distribución y gestión de las cuotas asignadas a España de especies demersales, en aguas comunitarias no españolas, de las subzonas Vb, VI, VII y VIIIa,b,d,e del Consejo Internacional para la Exploración del Mar.
} 
vessels are able to supplement their monthly landings limits from the pool with quota leased privately from other vessels. Where vessels have acquired additional FQA units, these effectively give rise to IQs. The SWFPO operates IQs for most of its membership, although a group of smaller inshore vessels do work within a quota pool. Many UK POs operating quota pools hold some FQAs centrally (on so-called "dummy" licences) which are used for the benefit of the membership as a whole. Both the CFPO and, to a lesser extent, the SWFPO, have invested in FQAs in order to secure additional quota for the membership as a whole. The CFPO also holds FQAs acquired by the Dutchy Fish Quota Company which aims to secure quota for the benefit of fishermen in Cornwall. Both POs assist their members with quota trading where required, for example by arranging exchanges ("swaps”) with other UK POs via the Marine Management Organisation (MMO), but are not otherwise actively involved in quota trading: there are a number of private companies which act as brokers in this market. Although day-to-day management decisions are taken by the PO offices, decisions on quota management approaches are taken by elected representative boards or at general meetings.

\section{Management progress}

504

Collecting information on fisheries management measures requires the implementation of both qualitative (Silverman, 2010) and quantitative techniques. This paper, however, relates only to the former. Firstly, semi-structured face-to-face interviews with fishermen's representatives were used to analyse fisheries governance issues, such as centralized or decentralized processes, relationships between local, national and European Government with stakeholders, the role of the Regional Advisory Councils (RACs), among others. Secondly, focus groups with fishermen were used to examine issues related to fisheries management measures and more importantly, issues related to fishermen's behaviour, in particular compliance behaviour. The main reason for the interview/focus group structure is the fact that

514 fishermen usually take part in the decision process via their representative's participation in 515 RACs and/or other fora, which makes it more difficult or easier for the 516 fishermen/representatives to speak freely about governance issues (De Vos and Van Tatenhove, 2011).

The economics of proximities (Torre and Rallet, 2005) is relevant in inter-organizational collaboration between stakeholders. Geographical and organizational proximities are the more

521 frequent dimensions used in the literature (Knoben and Oerlemans, 2006). Face-to-face 
522 interactions (questionnaires, focus groups, informal discussions) are facilitated with low 523 geographical distances and/or high organisational proximitiy (Torre and Gilly, 2000).

525 Each Western Waters case study selected the most appropriate technique (semi-structured 526 interviews or focus groups, or both) for collecting qualitative information on stakeholders' 527 (mainly fishermen's representatives or fishermen) perceptions of past and existing fisheries 528 management measures.

529 Semi-structured face-to-face interviews were organized to examine the French Producers 530 organizations managing the sole fishery in the Bay of Biscay. For the Irish fleets targeting the 531 Celtic Sea Herring fishery, face-to-face semi-structured interviews were conducted 532 simultaneously with choice experiment surveys. Additionally meetings of the management 533 advisory committee were attended as a research observer. In the Basque case study, 534 interviews were organized with local fishermen representatives, while focus groups were 535 organized with both local fishermen and local scientists. Information on devolved quota 536 management in South West England was obtained through semi-structured interviews with 537 representatives of the two Producers' Organisations (POs) which are responsible for the majority of fishing vessels in the region.

\section{$540 \quad$ France}

541 Semi-structured, face-to-face interviews were carried out with official representatives of all 9 542 French POs concerned with the sole fishery in the Bay of Biscay in June and July 2012 543 (Lagière et al. 2013). Limitations to fisheries access have changed fishing behaviour in 544 several main ways. Most fishermen acknowledged strong impacts of the progressive 545 implementation of individual quotas on fishing behavior. As a consequence, fishermen had to 546 adapt their fishing strategy either by increasing their fishing effort on sole fishery, or 547 diversifying their activity. In any ways, reallocating the production on others species was 548 necessary. Other changes relate to a reduced number of days at sea for the most specialised 549 gillnetters. Some exits from the industry or from sole fishery have been registered. Another 550 crucial issue addresses fishermen. Crew members are more attracted to vessels owning the 551 largest share of sole sub-quotas. Hence some POs are confronted with a deck-hand turnover 552 between members. These interviews showed that compliance with sub-quotas and national 553 quota is possible by strengthening the monitoring and management system of the fishery and 554 by more individualised production management within POs. 
557 How fishermen will respond to this access change and whether it will result in rationalization or consolidation of fishing rights is still uncertain, as the new policy has only been implemented since 2012. Information from PO representatives indicates that there is a growing appetite for tradeable licences within the fishery. A choice experiment survey conducted in this fishery in 2013 (Fitzpatrick et al, 2014b) indicates however that the majority of fishermen involved in the fishery are opposed to such tradeability. The access restriction itself created some conflict between fishermen as some felt that they were unfairly excluded from a fishery due to not participating when stocks were low. Another area where there has been an attempt to strengthen rights based management has been in the establishment of the sentinel fishery which has a twofold aim. Firstly to safeguard the interests of small scale fishing vessels by setting aside a fixed allocation of the quota and secondly to enhance the scientific knowledge base by allowing smaller vessels to fish inside an otherwise closed area and ensuring that scientists receive samples of catch from that area. The sentinel fishery is still an open access fishery for vessels under 10 meters and there are fears that the 2012 access restriction will produce an increase in participation in the sentinel fishery despite the limited quota available.

In the case of individual daily limits for mackerel stock, several elements have promoted noncompliant behavior from some vessel segments, following information derived from focus groups: (i) fishermen's expert knowledge on good mackerel stock status, (ii) the high level competition between purse-seiners, trawlers, and even the artisanal fleet for the mackerel stock, (iii) the seasonal character of the fishery and, (iv) the low level first-sale prices. With the aim of achieving good results in terms of the sustainability of this fishery, a new complementary and coercive top-down management by the Spanish administration was introduced, namely, a reinforced control system at ports. Thus, compliance and sustainability are possible only under coercive management. For the anchovy stock, managed by individual daily limits, the purse seine fleet is the only one that targets anchovy, hence the lack of incentive to compete for the resource. In relation to the market, the Bay of Biscay anchovy enjoys a well established reputation among consumers; this seems to protect the price from competition from anchovy imports. Finally, this measure provides correct incentives and contributes to the fishery's sustainability. In the case of IQs for blue-fin tuna, the role of the PO is perceived by the sector as very positive, having contributed to the success of this 
management system. In spite of this, fishermen do not think this experience could be applied to other fisheries in the Basque Country. The fourth experience concerns ITQs for hake, megrim and anglerfish. The offshore sector agrees with the ITQ system but claims that the roots of the sector's problem can be found in the initial allocation of the national share by the European Commission. The failures of the relative stability principle are argued as one of the main reasons for fishermen's behavior. Issues related to ITQ transfers among PO associates, among other issues, are organized through the PO concerned.

$U K$

UK fishermen can join any PO in any part of the country, however, so that although most POs do have a strong regional identity, members are often attracted by the quota management systems or specialisations offered by the PO. Thus, for example, the SWFPO membership includes beam trawlers and scallop dredgers from outside the Southwest, even Scotland. Although there is an active FQA/quota market in the UK, and fishing firms routinely use the money value of FQAs as security for bank loans, the legal position is that FQAs are not private property in law. This was tested recently in a UK High Court judgement which found that Government had the right to allocate FQAs as it saw fit, without financial compensation, and that fishing firms had no "legitimate expectation" that the rights conferred by FQAs amounted to possession. This is despite the fact that FQAs had been adjusted to reflect private quota trades three times (in 2001, 2005 and 2011). ${ }^{8}$

\section{Discussion}

Table 3 compares various co-management processes based on Sen and Nielsen's typology, offering a comparative approach of the regional management of fisheries between the northern (Ireland and UK) and the southern countries (France and Spain) in the Western Waters (Hadjimichael et al., 2013).

The sole fishery exploited by the French fleets (trawlers and netters) has been managed under individual quotas since 2006, with authority devolved from the State to POs. It is a decentralized procedure by delegation (co-management by delegation) from the French State with different regimes applied by POs depending on the local profiles of fishermen (specific rules for sharing the sole quota). Where fishermen have accepted this new regime for solving seasonal over-consumption of collective quota for sole, other controversial situations have

\footnotetext{
8 “High Court Spells Out Quota Rights”, Fishing News, 26 July 2013, p.2.
} 
623

624

625

626

627

628

629

630

631

632

633

634

635

636

637

638

639

640

641

642

643

644

645

646

647

648

649

650

651

652

653

654

655

656

occurred. Reallocating the fishing effort on other stocks is very limited. Securing attractiveness of the sole fishery is a crucial issue for fishermen and their representatives via POs and scientists.

The Irish Celtic Sea Herring fishery is currently managed as a partnership between an officially recognised, industry-led advisory committee, the Celtic Sea Herring Management Advisory Committee (CSHMAC) and the government. The CSHMAC makes operational level decisions such as the length of the season, the size of weekly allocations within that period and makes recommendations on issues such as how the quota should be allocated between fleet sectors and the definition of areas where fleet sectors may operate. The minister has the final say on these issues and critically retains decision making power over the issue of who has access rights.

Basque purse seiner fisheries are managed under a centralized regime via the Spanish State. This centralized regime is combined with self-management for quota pooling in the particular case of the bluefin tuna, and therefore the system can be best characterized as co-management by partnership. A specific scheme is applied for the anchovy fishery, where daily limits are adopted and managed within the "cofradía" as self-management. Traditional top-down hierarchical management by the state is applied to the mackerel fishery. In this last case, fishermen's behavior is subjected to strong control. For other fisheries regulations compliance contributes to the success of the management measures. Regarding Basque trawlers, the ITQ system comes from a centralized regime except for some issues. Pooling ITQs are organized within the corresponding PO under a self-management regime which contributes to the success of this fishery, with high regulatory compliance by fishermen. Again, this system can be considered to be “co-management by partnership”.

The English FQA/PO system can be best characterised as "co-management by partnership" since, given the quota allocation system decided at central government level the POs have a considerable degree of flexibility to manage quota at the local/sectoral level. It is important to appreciate that enforcement remains the task of Government while the ability to trade quota is restricted in the sense that permanent changes in quota "ownership” are still a relatively minor part of the overall trading activity. 
Table 3. A comparative approach of co-management in the Western Waters case studies

\begin{tabular}{|c|c|c|c|c|}
\hline Sub-case & Fleet & $\begin{array}{c}\text { List of management } \\
\text { measures }\end{array}$ & $\begin{array}{c}\text { Who are the local/regional } \\
\text { managers? }\end{array}$ & $\begin{array}{l}\text { Type of co- } \\
\text { management }\end{array}$ \\
\hline \multirow{2}{*}{$\begin{array}{l}\text { The } \\
\text { French } \\
\text { fleets }\end{array}$} & Bottom trawlers & \multirow{2}{*}{ IQs on sole since 2006} & $\begin{array}{c}\text { Government has delegated to } \\
\text { POs the introduction of }\end{array}$ & \multirow{2}{*}{$\begin{array}{c}\text { Co-management } \\
\text { by delegation }\end{array}$} \\
\hline & Gill-netters & & $\begin{array}{l}\text { individual quotas as a new } \\
\text { tool for fisheries management }\end{array}$ & \\
\hline \multirow{4}{*}{$\begin{array}{l}\text { The } \\
\text { Spanish } \\
\text { fleets }\end{array}$} & \multirow[t]{3}{*}{ Purse-seiners } & $\begin{array}{l}\text { Individual daily limits by } \\
\text { vessel for mackerel } \\
\text { stock. }\end{array}$ & $\begin{array}{l}\text { Initially proposed by the PO } \\
\text { concerned (i.e. OP } \\
\text { Cantabrico) Management by } \\
\text { the state (Spanish } \\
\text { Government) }\end{array}$ & $\begin{array}{l}\text { Top-down } \\
\text { hierarchical } \\
\text { management }\end{array}$ \\
\hline & & $\begin{array}{l}\text { Individual daily limits on } \\
\text { anchovy landings. }\end{array}$ & $\begin{array}{l}\text { Adopted within the } \\
\text { "cofradías" }\end{array}$ & $\begin{array}{c}\text { Self- } \\
\text { management }\end{array}$ \\
\hline & & IQs for blue-fin tuna & & \multirow{6}{*}{$\begin{array}{c}\text { Co-management } \\
\text { by partnership }\end{array}$} \\
\hline & Trawlers & $\begin{array}{l}\text { ITQs have been used in } \\
\text { the hake, megrim and } \\
\text { anglerfish fisheries and } \\
\text { scrapping subsidy }\end{array}$ & $\begin{array}{l}\text { Management by the state } \\
\text { (Spanish Government) and } \\
\text { pooling quotas organized } \\
\text { within the POs } \\
\text { (transferability) }\end{array}$ & \\
\hline \multirow{2}{*}{$\begin{array}{l}\text { The Irish } \\
\text { fleets }\end{array}$} & $\begin{array}{l}\text { Polyvalent } \\
\text { trawlers }\end{array}$ & $\begin{array}{l}\text { Limited access, weekly } \\
\text { quotas, spatial fishing } \\
\text { rights based on vessel } \\
\text { size. }\end{array}$ & \multirow{2}{*}{$\begin{array}{l}\text { Partnership between } \\
\text { CSHMAC (PO’s, fishermen, } \\
\text { processors, NGO, fisheries } \\
\text { control officer, scientist) and } \\
\text { government. }\end{array}$} & \\
\hline & $\begin{array}{c}\text { The sentinel } \\
\text { fishery }\end{array}$ & $\begin{array}{l}\text { Weekly quotas, fishing } \\
\text { in area, spatial fishing } \\
\text { rights based on vessel } \\
\text { size. }\end{array}$ & & \\
\hline \multirow[t]{2}{*}{$\begin{array}{l}\text { The } \\
\text { English } \\
\text { fleets }\end{array}$} & Trawlers/netters & $\begin{array}{l}\text { FQAs as a basis for PO } \\
\text { allocations: IQs or } \\
\text { monthly allowances (or } \\
\text { both) within individual } \\
\text { POs }\end{array}$ & \multirow[t]{2}{*}{$\begin{array}{l}\text { POs manage allocations from } \\
\text { central Government }\end{array}$} & \\
\hline & $\begin{array}{c}\text { Beam } \\
\text { trawlers/dredgers }\end{array}$ & $\begin{array}{l}\text { FQAs as a basis for PO } \\
\text { allocations: IQs or } \\
\text { monthly allowances (or } \\
\text { both) within individual } \\
\text { POs }\end{array}$ & & \\
\hline
\end{tabular}


One of the major recent trends in the European fishing sector has been the increasing role of the fishermen's cooperatives (e.g. Producer Organizations - POs) in quota management. Various forms of co-management have been used, by delegation, by partnership, through selfmanagement procedure or top-down hierarchical management.

In France, the Central Administration has gradually transferred the allocation quota procedures between fishermen to local level. In view of quota over-consumption situations, POs have had to introduce new rules within their organisations to impose limitations on individual consumption by species. In Spain this trend has been noted in the context of purseseiners where “cofradías” are able to manage anchovy on the basis of daily limits. In turn, blue-fin tuna are managed at the PO level on the basis of individual quota pooling. In the case of trawling, POs also manage the transferability of the ITQs. The Celtic Sea Herring fishery represents a fairly unique situation in Ireland as the local management committee has a strong input to quota management decisions while in other Irish fisheries quota management has not been devolved to the PO's. The introduction of a more defined restricted access regime in the main fishery has resulted in the issue of nationally-tradable quotas being discussed more frequently. In the UK, devolved management of quotas has a long history and the system of PO quota management is now well established. While differences remain between POs in the extent to which the market is permitted to play a role in their internal quota allocation, all POs now find they must allow some quota trading by their members. Whether the UK will follow the Netherlands and Denmark in moving any closer to an ITQ system proper (with continued PO responsibility) is unclear.

\section{Conclusion}

Several changes in the governance of quotas and the economic context have marked this recent period. Faced with increasing restrictions on accessing fish stocks, various new management measures have been introduced, including individualizing fishing rights, access limits and other specific measures. The main issues arising for the Western Waters from the latest CFP reform concern the implementation of landings obligations (discard bans). It remains to be seen how these will be introduced into the Western Waters fisheries but the devolved flexibility of quota allocation within the POs is likely to play an important role in matching catch and quota holdings. The implementation of these individual fishing rights schemes and other limited access regimes reflect the European debate on transferable fishing 
693 concessions within the CFP third reform. It would be a legitimate question to ask whether 694 public leasing among fishermen's organisation would be a sustainable system for the Western 695 Waters fisheries or whether the recently implemented system is on a "slippery slope” towards 696 market privatization (Lam and Pauly, 2010). It is too early to predict how attitudes and 697 perceptions with regard to quota trading and compliance may change as the discard bans start 698 to be put in place. We should perhaps highlight the fact that solving the discard problem may 699 require a more flexible approach such as quota swaps between POs of different member 700 states. 
Anon., 2012. Finaliza la mejor campaña de bonito en los ultimos 5 años, Europa Azul, No.132 Nov-Dic.

Appleby T., 2013. Privatising fishing rights: The way to a fisheries wonderland?, Public Law, pp. 481-497. ISSN 0033-3565

Aranda, M., Iriondo, A., Curtin, R. 2012. La flota vasca de altura al fresco: Análisis de su gestión y capacidad de pesca. Servicio de Publicaciones del Gobierno Vasco. In spanish.

Commission of the European Communities, 2009. Green Paper - Reform of the Common Fisheries policy, Brussels, 28p

Costello C., Gaines S.D., Lynham J., 2008. Can catch shares prevent fisheries collapse ? Science, 321, 1678-1681.

De Vos B.I., Van Tatenhove J.P.M., 2011. Trust relationhsips between fishers and government: New challenges for the co-management arrangements in the Dutch flatfish industry, Marine Policy, 35:218-225.

Department of Agriculture, Food and Fisheries, 2012. Management Arrangements and Fleet Policy Statement for Irish Herring fisheries, June 2012, Dublin, Ireland

EC (2013) Regulation (EU) No 1380/2013 of the European Parliament and of the Council of 11975 December 2013 on the Common Fisheries Policy, amending Council Regulations (EC) No 976 2371/2002 and (EC) No 639/2004 and Council Decision 2004/585/EC

Fitzpatrick M, Eigaard O., Maravelias C., Hynes S., Reid D., 2014a. In preparation. A Choice Experiment of Fishermen's Preferences for Future Management Options within the Common Fisheries Policy. In Press

Fitzpatrick M., 2014b. From boom and bust to local stewardship: a governance benchmark for Celtic Sea fisheries management. Chapter 3 in "Social issues in sustainable marine fisheries management”, edited by Urquhart, J. MARE Publication Series, Springer

Gezelius S.S., Raakjaer J., Hegland T.J., 2010. Reform drivers and reform obstacles in natural resource management: The Northeast Atlantic Fisheries from 1945 to the present, Human Ecology, 38:471-483.

Grafton R.Q., KompasT., McLoughlin R., Rayns N., 2007. Benchmarking for fisheries governance, Marine Policy, 31, pp470-479

Guttierez N.L., Hilborn R., Defeo O., 2011. Leadership, social capital and incentives promote successful fisheries, Nature, 470:386-389.

Hadjimichael M., Delaney A., Kaiser M.J., Edwards-Jones G., 2013. How Resilient Are Europe's Inshore Fishing Communities to Change? Differences Between the North and the South, Ambio, 42:1037-1046.

742 Hatcher A,. 1997. Producers' Organisations and devolved fisheries management in the United Kingdom: collective and individual quota systems. Marine Policy 21(6): 519-534

744 Hegland T.J., Ounanian K., Raakjaer J., 2012. Why and how to regionalize the Common 745 Fisheries Policy, Maritime Studies, 11:7.

746 Hilborn R., Orensanz J.L., Parma A.M., 2005. Institutions, incentives and the future of 747 fisheries, Philosophical Transactions of the Royal Society B Biological Sciences, 360:47-57. 
Holland D.S., Kitts A.W., Pinto Da Silva P., Wiersma J., 2013. Social Capital and the Success

749 of Harvest Cooperatives in the New England Groundfish Fishery, Marine Resource

750 Economics, 28, pp133-153

751 Jentoft S., 1989. Fisheries co-management: Delegating government responsibility to 752 fishermen’s organizations, Marine Policy, 13:137-154

753 Journal Officiel de la République Française (JORF) n_301 du 29 décembre 2006 page 19953 754 texte $n^{\circ} 104$ : Arrêté du 26 décembre 2006 établissant les modalités de répartition et de gestion 755 collective des possibilités de pêche (quotas de captures et quotas d'effort de pêche) des 756 navires français immatriculés dans la Communauté européenne. NOR: AGRM0602585A.

757 Knoben J., Oerlemans L.A.G., 2006. Proximity and inter-organizational collaboration: A 758 literature review, International Journal of Management Reviews, 8(2):71-89.

759 Lagière R., Macher C., Guyader O., 2013. Description des systèmes de gestion mis en place 760 par les OP dans le cas de la pêcherie de sole du golfe de Gascogne, Technical report, Ifremer, $76133 p$

762 Lam M.E., Pauly D., 2010. Who is right to fish? Evolving a social contract for ethical 763 fisheries, Ecology and Society, 15(3):16

764 Larabi L., Guyader O., Macher C., Daurès F., 2013. Quota management in a context of non765 transferability of fishing rights: The French case study, Ocean \& Coastal Management, $766 \quad 84: 13-22$

767 Marine Institute, 2012. The Stock Book, Report to the Minster for Agriculture, Food and the 768 Marine, Annual review of fish stocks in 2012 with management advice for 2013, Galway, $769 \quad 606 p$

770 Raakjær J., 2009. A Fisheries Management System in Crisis - the EU Common Fisheries 771 Policy. Aalborg University Press, Aalborg

772 Schlager E., Ostrom E., 1992. Property-rights regimes and natural resources: a conceptual 773 analysis, Land Economics, 68(3):249-262

774 Sen S., Nielsen J.R., 1996. Fisheries co-management: a comparative analysis. Marine Policy, 77520 (5): 405-418

776 Silverman, D., 2010. Doing Qualitative Research, London, Sage

777 Socioec, 2013. Critical report of current fisheries management measures implemented in EU 778 Western Waters, Socioec Research programme, Deliverable 69, Brussels, 62p 779 (http://www.socioec.eu/media-centre-4/socioec-deliverables)

780 Symes D., 2009. Reform of the European Union's Common Fisheries Policy: Making 781 fisheries Management Work, Fisheries Research, 100 :99-102.

782 Torre A., Gilly J.P., 2000. On the analytical dimension of proximity dynamics. Regional 783 Studies,34(2), $169-180$.

784 Torre A., Rallet A., 2005. Proximity and localization, Regional Studies 39: 1: 47-59. 